\title{
Quality Education of English Teaching in Chinese Normal University
}

\author{
Xiaorong Yang \\ Foreign Language School, West Normal University of China \\ NanChong, China \\ Ronghan97@163.com
}

\begin{abstract}
For the students of Normal University, college English is the process of language learning, as well as the implementation of quality-oriented education. This paper elaborated the importance and the necessity to cultivate the quality of Normal University students, and explored the way and strategy to improve students comprehensive quality through college English teaching and leaning.
\end{abstract}

Keywords-quality-oriented education; College English; comprehensive qualities; self-improvement

\section{INTRODUCTION}

As the main force of Chinese teacher education, quality education and comprehensive development of Normal university students are directly related to the rise and fall of teacher education as well as the whole education of China. As we know, the basic goal of normal university personnel training is to cultivate noble morality, to have stronger study capability, practice ability, and innovation spirit, furthermore, adapt to the national basic education reform and development of basic education. In 1996, the national education work conference pointed out clearly that the focus of teaching reform is "to improve the students' comprehensive quality", and the normal universities and schools are the models of quality education, as well as the key to the transition of basic education from examination orientation to quality orientation.[1] So the overall quality of students in normal university is the necessary prerequisite and fundamental guarantee to train a qualified, even outstanding teacher.

However, there are a lot of problems in cultivating students' quality education in normal universities of China. In recent years, because the number of college students increased rapidly, the teacher-student ratio fell into imbalance and the curriculum is not designed reasonable, which leads to the students' comprehensive quality decline, no correct learning attitude, and the lack of thinking and planning for the teacher occupation. Especially in many universities, English teaching is still the exam oriented education. College English Test Four or Six Band examination is still the basic teaching objectives. As a result, many students are entirely utilitarian learning without any intrinsic motivation and real interest, even lacking the humanities, as well as the overall quality. Therefore, how to combine the quality education and College English teaching, how to train students' humanities in the college English classroom, and how to improve their overall quality are the urgent need to solve.

\section{ENGLISH QUALITY EDUCATION OF CONSTRUCTIVISM}

As we know, the Normal education and the development of teacher's education are related to the level and quality of a nation's culture. As a public required course, college English has a large portion of all courses ( 3 credits per semester), and more classes(4 lessons a week). Thus college English teaching is the direct and effective way to promote the quality education of Normal University. The goal of English teaching is 'to cultivate students' comprehensive ability of using English, enhance their ability of independent learning, and improve the comprehensive cultural literacy". Based on this point, the training objectives of quality education for the students of Normal University and the teaching objectives of college English teaching are consistent. We may infer that only integrating the quality education into college English teaching is the best way to attain the goal of teacher education as well as the goal of college English teaching. From this point, the view of Knowledge constructivism, which focuses on students' center, teaching interaction and the integration of situation and knowledge acquisition, can be the basic theory of quality education.[3] In this study, the quality education of constructivist view includes the following two aspects:

\section{A. Student-centered classroom teaching}

The model of student centered English classroom teaching is an effective way of implementing quality education. The process of training students' learning and autonomous ability is also the process of training the students' subject consciousness. Constructivism learning view regards learning as a process in which learners construct knowledge actively and learners construct understanding in their own way. Therefore, in the university English classroom, students are not only positive recipient of language as well as the subject of learning and an active creator. For the future teachers, subject consciousness is the key of whole quality training.

In the process of teaching, first of all, teachers should create actively a real language situation and give students more listening and speaking practice; secondly, should design carefully for teaching and classroom activities and give students more opportunity to have the self display, such as duty report, speech, role-playing; further more, should adjust the different roles of teachers and the students. In this process, students are no longer accepting knowledge passively, but on 
the whole, they changed to be the center of teaching activities. In this way, positive cooperation between teachers and students not only can cultivate students' learning interest, but also can effectively cultivate their subject consciousness, so as to improve the overall quality of students.

\section{B. Web-based autonomous learning}

At present day, web-based English Autonomous Learning Mode provides a new open learning environment for college students, which take the place of traditional teaching in classroom. Thus the teaching effect depends largely on the students' subjective initiative and active participation. Web-based autonomous learning emphasizes students' self control and students' management, which are the important conditions to construct knowledge.[4] In order to cultivate the quality education, web-based autonomous learning can be carried out from the following aspects:

First of all, students' phase learning plan is developed, and an overall arrangement is made by students for their learning contents. Then students must learn to preview and review, and they can study and explore actively from the passive acceptance. What's more, under the guidance of teachers, students' self regulation and management are promoted and form their own individual learning strategies, so as to improve their ability of autonomous learning as well as cultivate their comprehensive quality.

\section{QUALITY TRAINING IN THE ENGLISH CLASSROOM}

Based on constructivism, students regard the network as a platform to strengthen the training of their own subject consciousness, which is the premise of the implementation of quality education in college English teaching. Because humanity reflects the social demand and value orientation of their own development and it also reflects the people's ideal, belief, moral, emotional and spiritual pursuit.[5] As a compulsory course, college English plays a vital role in the training of Normal University students' quality. How to cultivate and improve students' comprehensive qualities through college English teaching, some suggestion are provided:

\section{A.The training of ideological quality}

College English teaching is not just simple language learning, but also a course to cultivate moral character of students. Good moral character is particularly important for the students of Normal University. To cultivate students' patriotism, collectivism and socialist ideology in higher schools is the soul and goal of quality education.[6] As future teachers, first of all, the students of normal university should take the social and historical responsibility.

In the process of English learning, although the culture of other countries are concerned mostly, some materials, which are related to our own native cultures, our own society and times, also should be selected as the teaching materials, such as China Daily, 21st Century, Shanghai Star, etc. At the same time, we should strengthen students' ideological quality and enable the students to have the correct outlook on life and values. For example, in the English integrated Course (Book Two), the topic "A Life Full of Riches" enable students to have a deep understanding of the value of human life and wealth. Another case is the topic "The Woman Can Learn Anything a Man Can" is a persuasive case that students may learn how to get the self-respect. We may conclude that the ideological quality is the important premise of cultivating the students' comprehensive qualities.

\section{B. Cultivation of teachers' moral quality}

A fundamental difference between the Normal University students and general university students is that the Normal University students have the clear goal of future occupation. So in the process of English teaching, the moral quality of normal school teacher occupation should be strengthened, such as occupation attitude, occupation responsibility, occupation conscience and occupation moral style, especially, their dedication for their work and love for their students. As in the College Intensive Reading (Book Three), the article "why I teach?" is a classic essay, which sets a model of an excellent teacher for students, and makes students know their future occupation for specific. And in the College English Integrated Course (book one), the article "Writing for Myself" is creating a concrete image of a good teacher who has the teaching art, which make students gradually develop their dedication for their teacher occupation in the English learning process.

\section{The cultivation of psychology quality}

University English course is usually set up in grade one or two of university. This stage is the most intense period of psychological change for students, as well as the psychological perplexity and psychological conflict, such as inadaptability after entering the university and the huge psychological gap brought by the new life and learning environment of college. As a result, students may have the psychological conflicts or confusion fierce, such as emotional instability, weak emotional self-control ability, social indifference or frustration tolerance. So in the process of English learning, first of all, the importance of humane should be emphasized, such as in the new "College English Integrated Course"(Book One), the article "All the Cabbie Had Was a Letter" let the students feel the power of friendship, the article "A Valentine Story" demonstrate the charm of love for human. Secondly, students should cultivate strong will and a positive, even optimistic attitude towards life. Such as the article "True Height", the struggling story of a blind man encouraged moved and encouraged students. Strong will and aggressiveness are also the important aspects of basic quality training for the future teachers.

\section{Development of the language and cultural quality}

Of course, College English learning is a process of language quality, which includes the ability of language skills and communicative competence of English, so training the language quality and cultivating students' cultural accomplishment are also the focus of quality education.

When language is used in the communicative context, it must take a compound or complex way connected with culture because "language expression is the inclusion of cultural reality".[7] College English is a humanity course of cross cultures, which contains a lot of import culture information of mother tongue and the target language and can 
directly affect the students' world outlook, values, so as to enhance the ability of cross cultural communication, even improve students' humanistic quality,. In the process of teaching, a large number of written and audio-visual materials related to the western history, religion, culture and local customs can be adopted, so that the students can experience the culture in language learning and learn language in culture, furthermore, their intercultural communication can be developed. In the text book "audio-visual reading" published by Shanghai Foreign language Press, students may be provided the chance to appreciate the charm of the different cultures. The real material and the cultural experience can stimulate students' interest in learning and broaden their horizons, especially strengthen the cultivation of their cultural quality.

\section{CONCLUSION}

For the students of Chinese Normal University, English learning is an effective way to develop their comprehensive quality. However, some problems should be paid attention to:

\section{A. Ccorrect understanding for the western and the native culture.}

It is necessary to foster the culture of target language during the process of cultivating the cultural quality, as well as the important training condition for the students to communicate in English. But at the same time, we should train students to use critical thinking to study the target culture. Secondly, students should be fully aware of the cultural difference between East and West, so they can easily change their inherent mode of thinking to learn English and use English better. Of course, at the same time, the native culture can not be ignored. Only one and more cultures blend each other, can we cultivate students' ability of cross-cultural communication, thus to cultivate students' cultural quality.

\section{$B$. Correct understanding for the relationship between} exam-oriented education and quality-oriented education.

Compared with the exam oriented education, quality oriented education can fully stimulate the potential of students and make students all-round development. However, how to find a balance between the two extremes is a puzzle to many educators. Only the correct and rational attitude towards quality-oriented education and exam oriented education can solve the conflict.

\section{Reasonable evaluation system for the quality education.}

For the evaluation of quality education, the multi-dimensional evaluation system can be utilized, such as psychological quality, professional quality and cultural quality, etc. The test or examination content should be designed and closely related to quality education. Perfecting the evaluation system will further promote quality education, improve the enthusiasm of the students' self consciousness, and develop the quality education to the benign direction.

\section{Continuous improvement of College English teacher}

As a compulsory course in Normal Universities, English is a good way to cultivate the students' quality education. Thus the quality of College English teacher has a direct impact on the effective implementation of quality education. The exemplary role of teachers is a powerful factor of education. [7] They not only should have the personality characteristics of noble, but also should have a good professional and comprehensive quality, especially to make their own quality continuously upgrade, such as educational philosophy, constant reflect and improvement on their teaching behavior, and teaching methods.

\section{REFERENCES}

[1] Jiang Defu, The goal of Training Normal College Quality Education [J], The modern education management 1997.03, p128.

[2] Guchi, English quality education in University [J], Journal of Xianning University 2010.08, p170.

[3] Yang Xiaorong, Role of foreign language teachers under the mode of Web-based Autonomous Learning [J]. Journal of Changchun University of Science and Technology 2010,05 , p 64.

[4] Du Xiujun\&ZhangFang, 2009. Teaching the humanistic quality education By College English Teaching [J]. Journal of Jilin Normal University 2009,02, p 89.

[5] Zhang Qingfeng, 2001. Quality Education in College English Teaching [J]. China Electric Power Education, 2001,10, p 223.

[6] Clair Kramsch, Language and Culture, Oxford University, 1998, p3..

[7] ChenFan \& ZhenYong, College English teaching and students' humanities quality[J]., China Adult Education 2008.03, p183. 